\title{
Dynamic performance of the D-Bolt
}

\author{
C.C. Li The Norwegian University of Science and Technology (NTNU); Dynamic Rock Support AS, Norway \\ F. Charette Dynamic Rock Support AS, Norway/Canada
}

\begin{abstract}
The D-Bolt is a rock bolt that is specially designed to absorb energy through elongation of the bolt material. The standard version of the bolt is a smooth steel bar with a number of anchors along its length. The sections between anchors are approximately $1 \mathrm{~m}$ long. The rock bolt is encapsulated in a borehole with either cement grout or resin. Whilst the anchors are encapsulated in grout, the smooth sections between the anchors can freely deform when subjected to rock dilation. Every section between two adjacent anchors works relatively independently. Failure of one section does not affect the reinforcement performance of the other sections. The bolt is designed to fully use both the strength and the deformation capacity of the bolt material along the entire length of the bolt, thus, it offers a large energy-absorbing capacity. The principle of the bolt, the static pull tests and field tests are briefly reviewed in the paper. The emphasis if the paper is put on the dynamic performance of the bolt with updated data of impact tests. The impact load tests were conducted in CAMNET's laboratory, Canada. For impact tests, the length of the tested segments of the $22 \mathrm{~mm}$ D-Bolts was $0.9 \mathrm{~m}$. The drop height was kept at $1.5 \mathrm{~m}$, and the drop weight varied from 893 to $2,675 \mathrm{~kg}$. The corresponding input energy ranged from 13 to $39 \mathrm{~kJ}$. At the input energy of $39 \mathrm{~kJ}$, the $0.9 \mathrm{~m}$ long test segment elongated about $0.14 \mathrm{~m}$ at an impact load level of about $280 \mathrm{kN}$ after one drop. The dynamic energy absorption of the $22 \mathrm{~mm}$ bar specimen is $39 \mathrm{~kJ}$ for a $0.9 \mathrm{~m}$ long section, corresponding to $43 \mathrm{~kJ} / \mathrm{m}$. The static load capacity of the $22 \mathrm{~mm}$ bolts is about $250 \mathrm{kN}$.
\end{abstract}

\section{Introduction}

The D-Bolt is an energy-absorbing support device that differs from other energy-absorbing bolts by its multipoint anchor design, The other energy-absorbing bolts, such as the cone bolt (Jager, 1992; Simser et al., 2007), Garford solid bar (Varden et al., 2008) and Roofex (Charette and Plouffe, 2007), have a two-point anchor design, with an inner anchor in the bottom of the hole and an outer anchor (i.e. the bolt plate) on the wall surface. The D-Bolt provides a satisfactory support performance through the mobilisation of the load and deformation capacities of the bolt material (steel) along its entire length. The energy absorption of the bolt is approximately identical for both static and dynamic loading conditions. A brief review is given to the principle of the bolt, static pull tests and field tests in this paper. Refer to Li (2010) for more details on those aspects. The emphasis of this paper is put on the dynamic performance of the bolt with updated dynamic test data.

\section{$2 \quad$ Layout and principle}

The D-Bolt is made of a smooth steel bar that has a number of integrated anchors evenly or unevenly spaced along the length of the bar. Figure 1 is a sketch of the D-Bolt. The number of anchors or sections can be decided based on rock conditions. Figure 2 shows $2.2 \mathrm{~m}$ long D-Bolts with three anchors. In the current design, the first anchor is located closely to the thread/plate, aiming to reduce the load on the thread/plate. The first anchor and the last anchor at the far-end of the bolt are made so that they are firmly fixed in the grout, while the in-between anchors are either firmly fixed in the grout or allowed to plough at a predefined load level. The D-Bolt is fully encapsulated in the borehole with either cement or resin grout. The anchors are locked in the grout, while the smooth bar sections between anchors have very weak or no bonding to the grout due to the smooth surface of the bar. When the rock dilates between two adjacent anchors, the anchors tend to restrain the rock dilation so that a tensile load is induced in the smooth bar section. The section elongates elastically in the beginning, but it will soon yield after sufficient rock dilation. After which, the bar section elongates plastically until the ultimate strain limit is reached. A mild carbon steel, such as the steel for ordinary rebar bolts, has an ultimate strain of $15-20 \%(\mathrm{Li}, 2010)$ for a standard test length of about 
$200 \mathrm{~mm}$. The ultimate strain of some special steels, for instance TRIP/TWIP steels, can be up to $60 \%$ (Grassel et al., 2000). A rock bolt made of steel can absorb a significant amount of energy when its deformation capacity is fully mobilised.

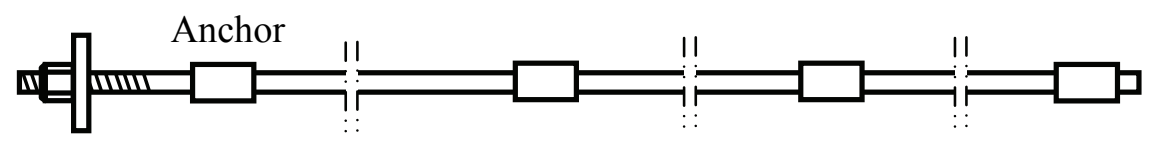

Figure 1 Layout of the D-Bolt

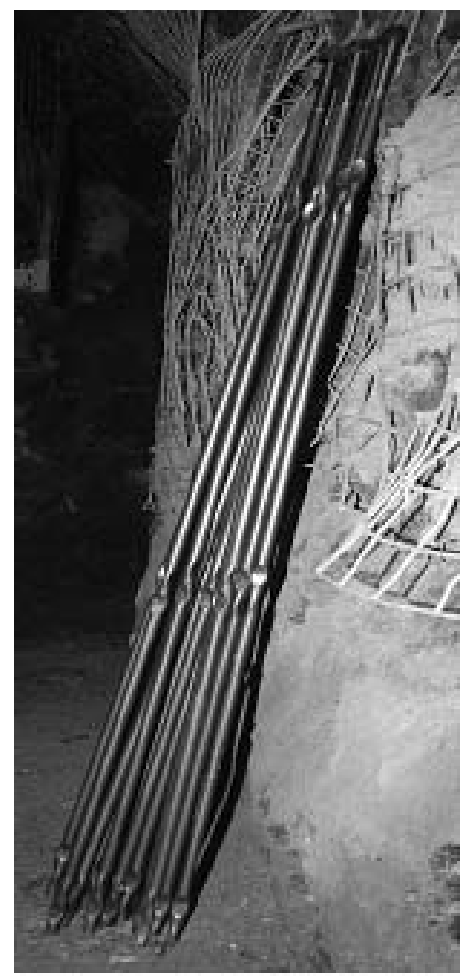

Figure 2 D-Bolts; $2.2 \mathrm{~m}$ long

The reactions of a rebar and a D-Bolt to opening of single fractures are illustrated in Figure 3. A rebar is bounded to the grout along its entire length. Opening of a single fracture would only locally load the rebar, inducing a high tensile stress in a short axial length of the rebar, as shown in Figure 3a. Pull tests show that fully encapsulated rebar bolts fail at an ultimate elongation of $20-30 \mathrm{~mm}$, see the curve for rebar in Figure 5 . Assuming an ultimate strain of $15 \%$ for the rebar steel, an elongation of $20-30 \mathrm{~mm}$ corresponds to a deformation of a $0.15-0.20 \mathrm{~m}$ long section which is fully mobilised in its deformation capacity. In the case of a D-Bolt, the opening of a single fracture will load the entire length of the section between the adjacent anchors. The axial strain induced in the D-Bolt section is conceptually smaller than that of the rebar. For a one-meter long D-Bolt section, a fracture opening of $20 \mathrm{~mm}$ only induces $2 \%$ strain in the section. Such a strain is well under the ultimate strain limit (around 15\%) of the bolt material.

\section{$3 \quad$ Full-scale static pull tests}

Static pull tests of different scales were conducted in the rock mechanics laboratory at the Norwegian University of Science and Technology (NTNU), Norway. Short bar specimens had a segment length of about $0.3 \mathrm{~m}$. The test results of the short bar specimens were presented in detail by Li (2010). Here is a brief review of the results. Both resin and cement mortar were used as grout. There were no difference for the results for resin and cement grouts. The tensile strength was $210 \mathrm{kN}$ for the $20 \mathrm{~mm}$ bar specimens and $250 \mathrm{kN}$ for the $22 \mathrm{~mm}$ specimens. The specimens failed at a maximum strain of $14-18 \%$. 
Full-scale pull tests were conducted at NTNU in 2010, using a bolt test rig, Figure 4. For these tests, rock mass was simulated by two concrete cubic blocks with a uniaxial compressive strength of approximately $110 \mathrm{MPa}$ and dimensions of $0.95 \times 0.95 \times 0.95 \mathrm{~m}$. Boreholes were drilled by a $32 \mathrm{~mm}$ drill bit through the concrete blocks in the longitudinal direction after the blocks were placed in the frame of the test rig. The bolts were cement encapsulated in the borehole and the grout was cured at least three days. A plate was attached to the thread end of the bolt. When testing, one of the concrete blocks was fixed and the other one pulled longitudinally by two hydraulic jacks. The displacement of the pulled block was measured with a linear variable differential transformer (LVDT). A load cell was placed under the plate to measure the load transferred to the plate.

The D-Bolt specimens tested were $20 \mathrm{~mm}$ in diameter and $2 \mathrm{~m}$ long and had two anchors. Every anchor was composed of two ovals forged on the bar. The smooth bar length between the two anchor positions, i.e. the test segment, was $0.825 \mathrm{~m}$. The test results of two specimens are shown in Figure 5. Specimen OP1 was not coated, while specimen OP2 was coated with a plastic sleeve in the test segment. Specimen OP1 failed at a maximum elongation of $108 \mathrm{~mm}$ corresponding to a strain of $13 \%$. The maximum plate load was approximately $100 \mathrm{kN}$. Specimen OP2 failed at a maximum elongation of $121 \mathrm{~mm}$ corresponding to a strain of $14.7 \%$. The coating increased the elongation by $1.7 \%$. The increment of the elongation by coating can be considered limited. In effect, the tests demonstrated that the smooth cylindrical surface of the bolt shank can satisfactorily detach from the grout under pull loading without any surface treatment. The tensile strength of the bolt shank was about $211 \mathrm{kN}$ for both OP1 and OP2. The work energy was $23 \mathrm{~kJ} / \mathrm{m}$ for OP1 and $26 \mathrm{~kJ} / \mathrm{m}$ for OP2.

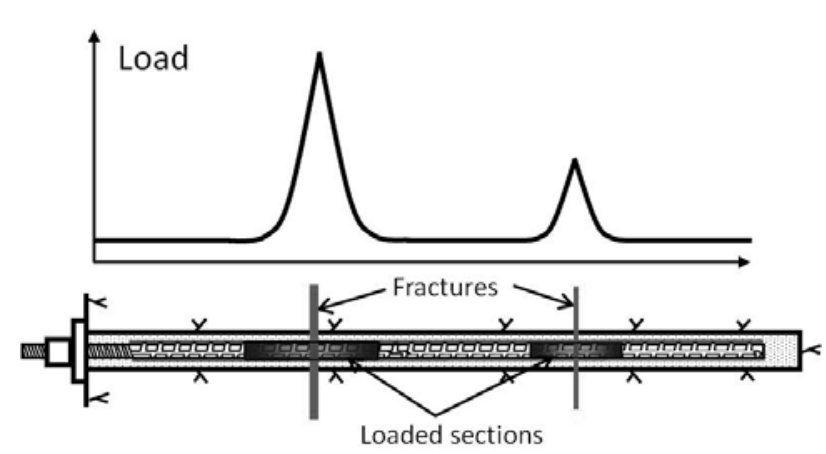

(a) Loading pattern in a rebar

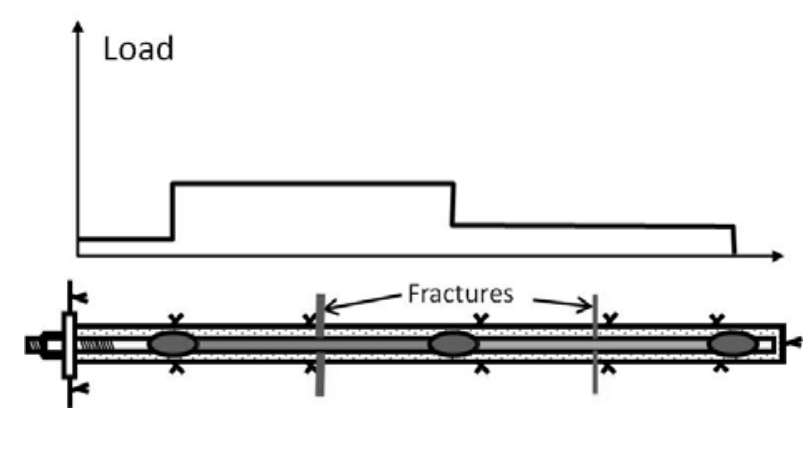

(b) Loading pattern in a D-Bolt

Figure 3 Sketches illustrating the loads induced in a rebar and in a D-Bolt when they are subjected to opening of single fractures

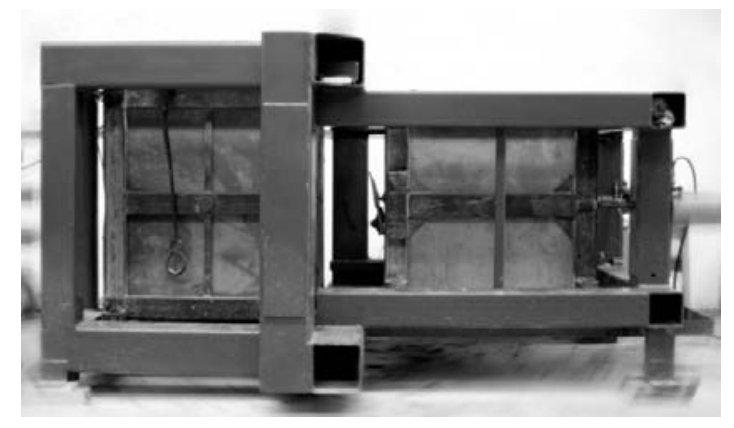

Figure 4 Test rig for full-scale static pull tests

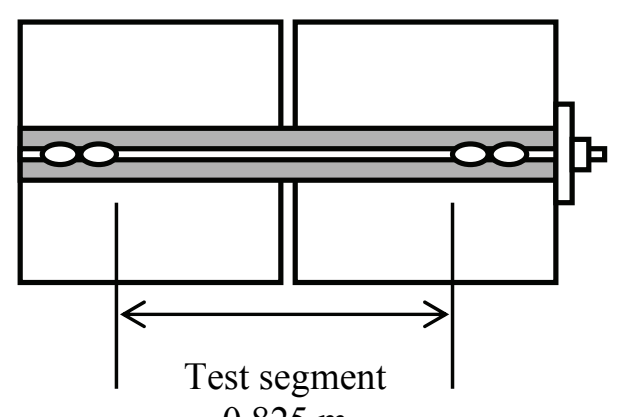

$0.825 \mathrm{~m}$ 


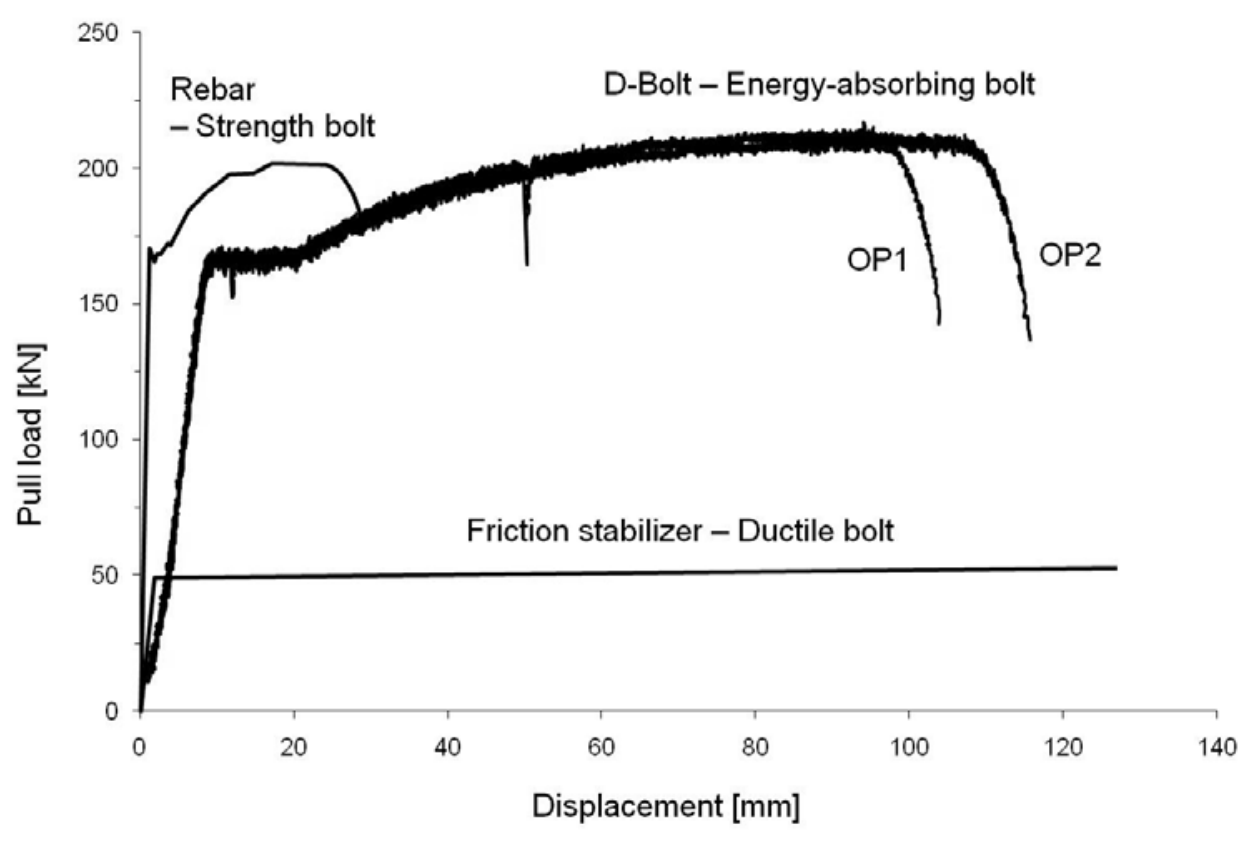

Figure 5 Pull test results of $O$-anchor specimens OP1 and OP2. The pull test results of a rebar in cement grout and a split set bar are also shown in the figure, for comparison

\section{$4 \quad$ Field tests}

Field tests were conducted at a depth of about $1100 \mathrm{~m}$ in the Kristineberg mine, Sweden, which is characterised by its weak formations and high in situ stresses. The mine's drifts and stopes are usually subject to squeezing ground conditions. The mine uses cement-grouted rebar bolts with a bolting pattern of $1 \times 1 \mathrm{~m}$ as its standard ground support device. Fifty pieces of D-Bolts were installed with cement grout in three places with the same bolting pattern as the rebar. Three pieces of D-Bolts and two pieces of rebar bolts were instrumented with strain gauges. The instrumented bolts were installed in two mine stopes and in two ramps. The bolts were $20 \mathrm{~mm}$ in diameter and $2.7 \mathrm{~m}$ in length. The measurement data of only two instrumented D-Bolts and one rebar are available since the others were damaged by blasting. The axial loads measured in one of the two D-Bolts (the other one had a similar loading condition) and the rebar are presented in Figure 6. In the rebar bolt, the maximum load occurs at the position close to the thread/plate. The bolt load, in general, decreases with the distance from the stope wall. However, two load peaks occur in the length of the bolt, one in a depth of about $1.3 \mathrm{~m}$ and the other close to the far-end of the bolt. A number of previous extensometer measurements conducted in the mine (unpublished data) confirm that a major fracture zone was located in the depth of 1.0-1.5 m behind stope walls. The load peak of the rebar bolt in the depth of $1.3 \mathrm{~m}$ could possibly be attributed to the fracture zone there. The D-Bolt was also mostly loaded in the section close to the thread/plate and least loaded in the far-end section. Results shown in Figure 6 demonstrated that the load of the D-Bolt is constant in every section; and the load in the section close to the thread/plate of the D-Bolt is significantly lower than the maximum load in the rebar. The constant load in the sections shows that the D-Bolt is not as significantly affected by local stress concentration owing to fracture zones as rebar. Thus D-Bolts could potentially sustain more deformation than rebar bolts.

Installation tests were conducted with resin grout in two deep mines in Canada. The D-Bolts were $22 \mathrm{~mm}$ in diameter and $2.2 \mathrm{~m}$ in length. The bolts were installed on MacLean bolters. Two types of resin were used in every bolt hole. The bolts were spun into the hole in about 10 seconds at a rotation speed of 350-500 RPM. All the bolts were installed without difficulty. Some of the installed bolts were pulled to examine their loadbearing capacity. In one of the mines, five bolts were pulled to 190-210 kN without slippage (Cai and Champaigne, 2009), indicating that the resin was well mixed and the anchors were firmly fixed in the resin. More details regarding the field tests can be found in $\mathrm{Li}(2010)$. 


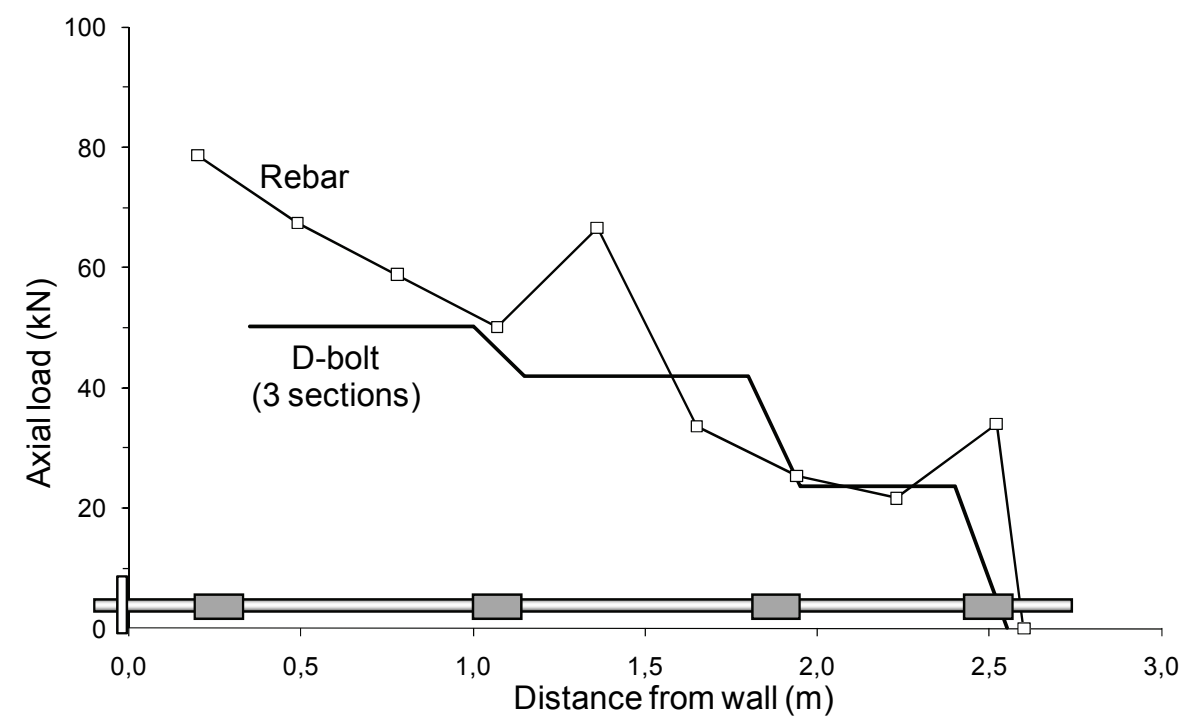

Figure 6 Load distributions in a rebar and a D-Bolt measured in the field

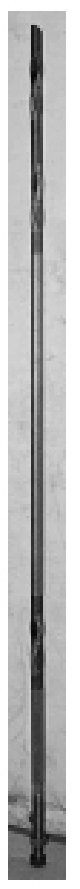

(a)

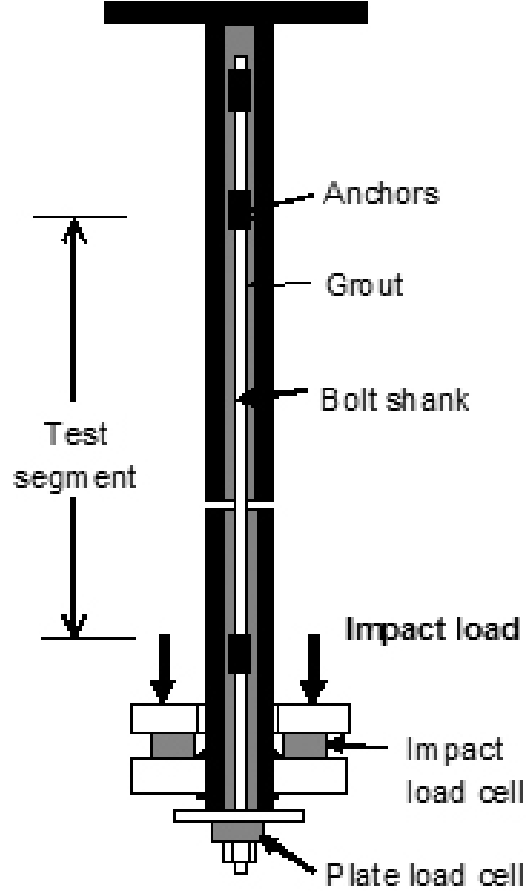

(b)

Figure 7 Drop test arrangement; (a) bolt sample (b) alignment of the test

\section{$5 \quad$ Dynamic drop tests}

The first series drop tests were carried out in 2008 to evaluate the dynamic energy absorption capacity of the D-Bolt (Li et al., 2009). For those dynamic tests, boreholes were simulated by split steel tubes which are 32 or $34 \mathrm{~mm}$ in inner diameter and $12 \mathrm{~mm}$ in wall thickness. The split tube was placed in a jig to align it with the drill. Resin cartridges were then slid to the end of the tube. The bolt was inserted in the chuck of the drill mounted on a sliding rail with an independent advance drive system. The bolt was spun into the tube with a steady advancement and constant rotation speed. 
The test arrangement is shown in Figure 7. Every test consists of dropping a mass of 893-2,679 $\mathrm{kg}$ from a height of $1.5 \mathrm{~m}$ onto a plate connected to the D-Bolt. The nominal input energy, the potential energy of every drop, was equal to 13-39 kJ. The weight was lifted using an electromagnet, lifted by a pair of cranes mounted in parallel on the top of the machine. The weight was left to freefall onto the specimen by cutting the power to the magnet.

The plate and end displacements of the bolt were measured by line scan cameras. The plate displacement refers to the displacement measured at the bolt plate, while the end displacement refers to the movement of the bolt end. The difference between the two displacements is the elongation of the test segment. The load cell below the impact plate measures the impact load and the load cell below the bolt plate measures the load received by the bolt plate.

In the first series tests, the specimens were $20 \mathrm{~mm}$ in diameter and had $0.8 \mathrm{~m}$ long test segments. The specimens were drop loaded with an input energy of $13 \mathrm{~kJ}$. Three drops had to be done to break the specimens. In the second series tests that were conducted in 2009, the specimens were $22 \mathrm{~mm}$ in diameter and had $0.9 \mathrm{~m}$ long test segment lengths. The specimens were drop loaded with an input energy of 30-39 kJ. The specimens tested with an input energy less than $36 \mathrm{~kJ}$ did not fail after the first drop. The specimen tested with $39 \mathrm{~kJ}$ failed at the first drop. Figure 8 shows the curves of the impact load and the plate load registered during the drop for the specimen tested with $39 \mathrm{~kJ}$. The impact average load of the specimen was about $285 \mathrm{kN}$, while the plate load was about $85 \mathrm{kN}$. In general, the load transferred to the plate was only about $20-40 \%$ of the impact load. The fact that a small portion of the impact load was transferred to the plate indicates that the anchor close to the bolt thread provides a protection to the thread and the plate when the bolt is subjected to dynamic loading.

The load-elongation curves of two specimens are shown in Figures 9 and 10. Figure 9 is the result of a specimen that was dropped with a mass of $2,452 \mathrm{~kg}$ from a height of $1.5 \mathrm{~m}$, corresponding to an input energy of $36 \mathrm{~kJ}$. The specimen elongated for about $136 \mathrm{~mm}$ without failure. Figure 10 is the result of a specimen that was dropped with a mass of $2,675 \mathrm{~kg}$ from a height of $1.5 \mathrm{~m}$, corresponding to an input energy of $39 \mathrm{~kJ}$. The specimen elongated for about $140 \mathrm{~mm}(16.4 \%$ strain) and then failed. These two specimens are $22 \mathrm{~mm}$ in diameter and approximately $0.9 \mathrm{~m}$ long for the test segment. The tests show that the maximum one-drop work energy absorption for such a section is about $39 \mathrm{~kJ}$.

Figure 11 shows that the elongation of the test segment versus the input drop energy. The elongation increases approximately linearly with the input energy. The elongation at $13 \mathrm{~kJ}$ was calculated from a specimen of $22 \mathrm{~mm}$ in diameter and $0.9 \mathrm{~m}$ in length.

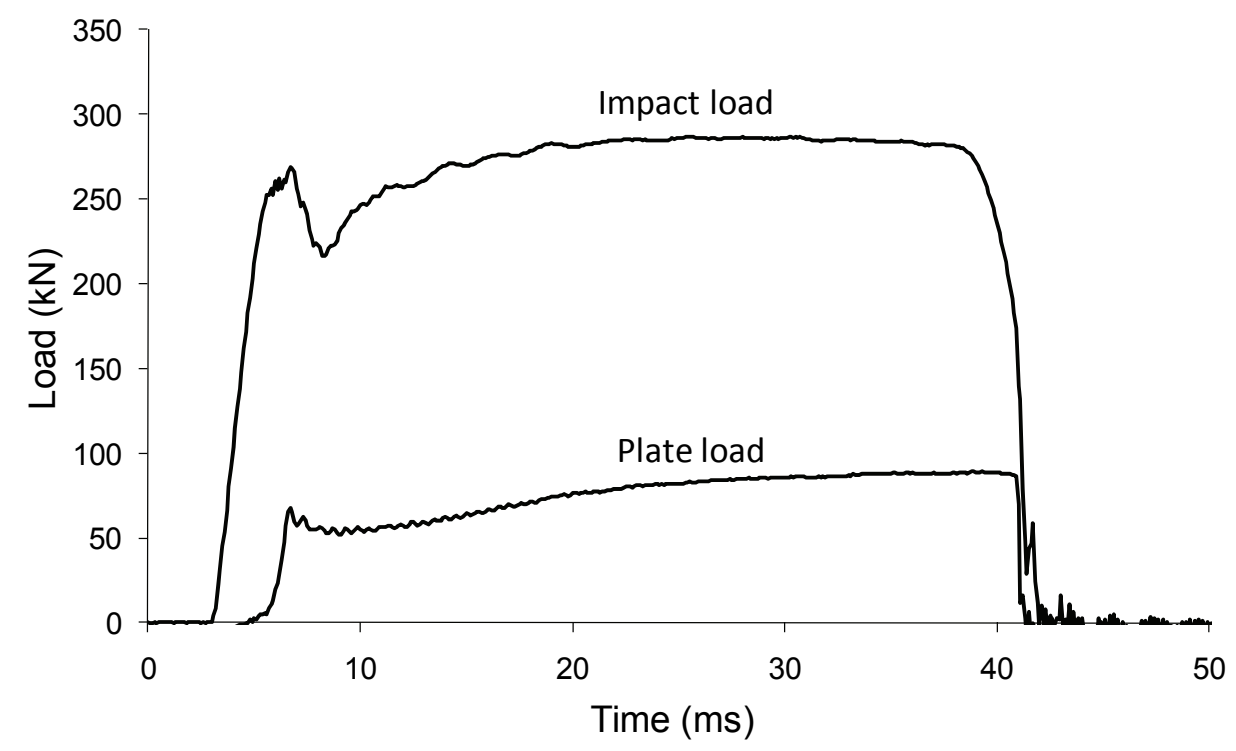

Figure 8 The impact and plate loads registered during dynamic drop testing for input energy of $39 \mathrm{~kJ}$ and a test segment of $22 \mathrm{~mm} \times 0.9 \mathrm{~m}$ 


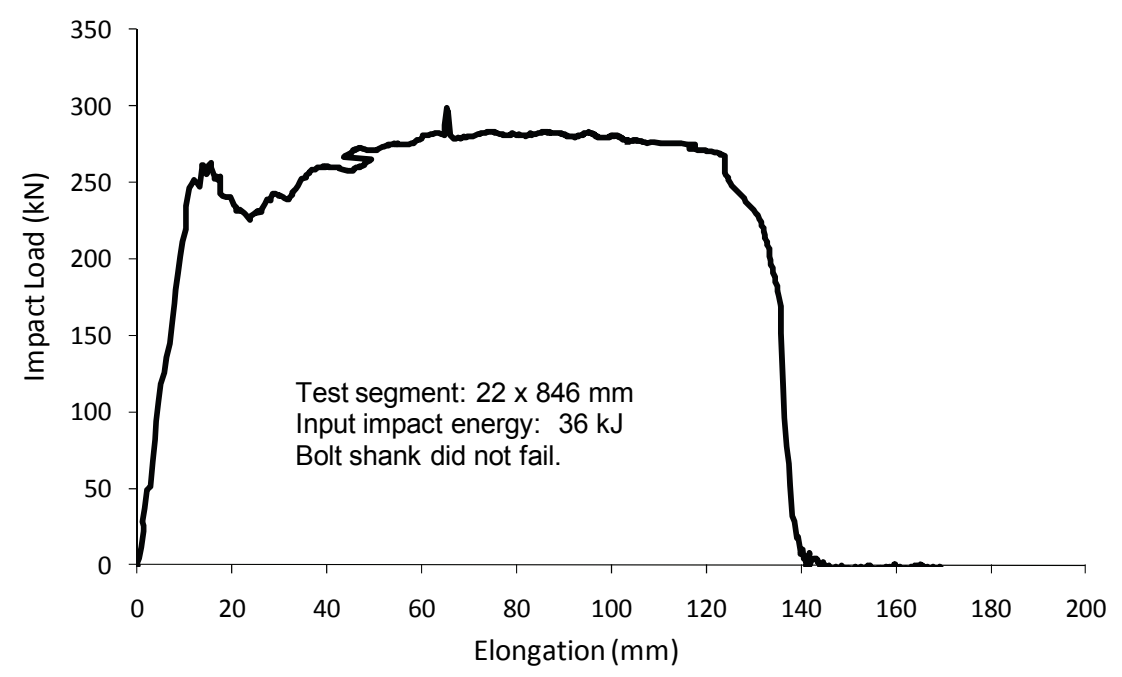

Figure 9 Impact load versus elongation for a specimen with an input energy of $36 \mathrm{~kJ}$ (drop weight $=$ $2,452 \mathrm{~kg}$ )

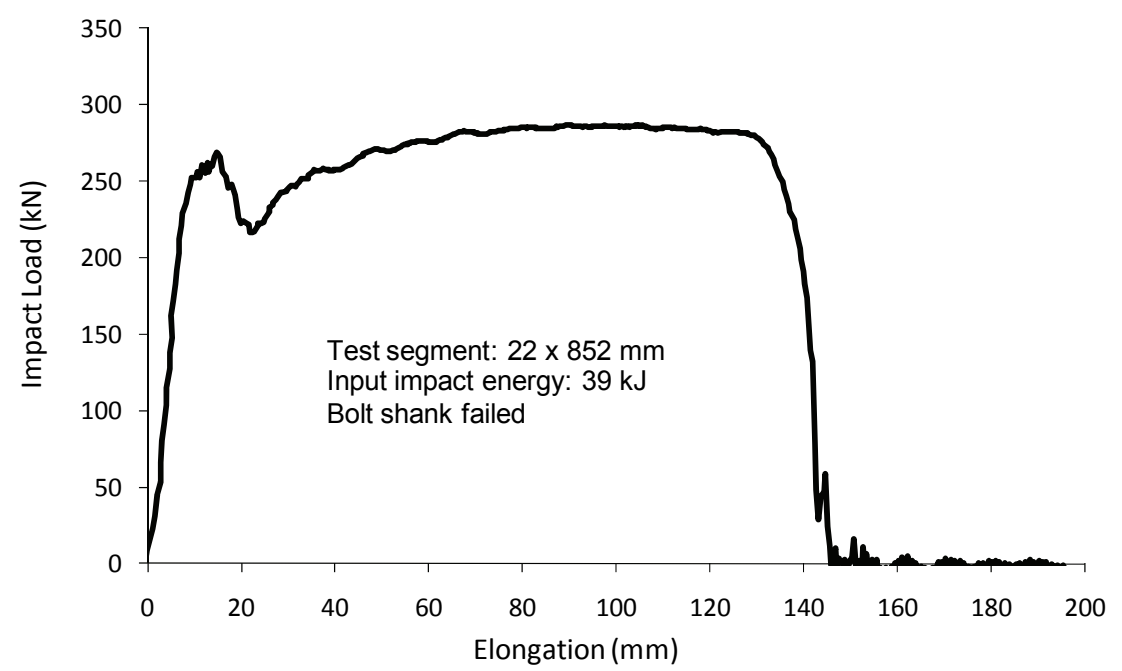

Figure 10 Impact load versus elongation for a specimen with an input energy of $39 \mathrm{~kJ}$ (drop weight $=$ $2,675 \mathrm{~kg}$ )

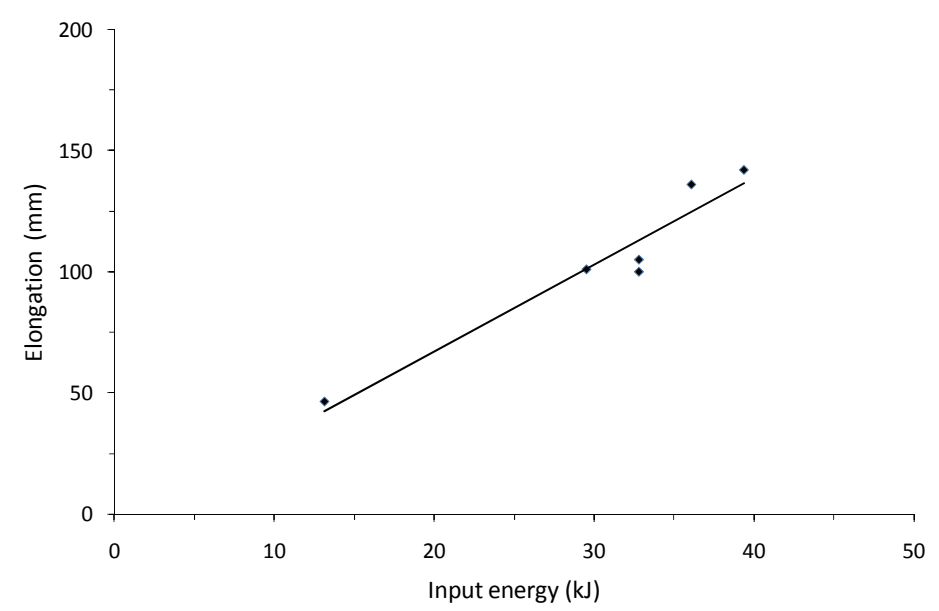

Figure 11 Elongation versus input energy for a test segment of $22 \mathrm{~mm}$ in diameter and $0.9 \mathrm{~m}$ in length 


\section{Conclusion}

This article presented static and impact test results for D-Bolt specimens with emphasis on the latter. The DBolt is a multi-point anchor steel bar installed in a fully grouted borehole. The bolt absorbs energy through full mobilisation of the strength and the deformation capacity of the bolt material (steel) in its entire length.

The static pull tests show that the bolt shank can elongate for a large amount, since the deformation capacity of the steel is fully mobilised in the D-Bolt. Such a rock bolt can provide a high load-bearing capacity and also tolerate large deformations as compared to other commercially available rock bolts. The tensile strength of the specimens was $210 \mathrm{kN}$ for the $20 \mathrm{~mm}$ bars and $250 \mathrm{kN}$ for the $22 \mathrm{~mm}$ bars. The specimens failed at a maximum strain of $14-18 \%$.

The dynamic drop tests show that at the input energy of $39 \mathrm{~kJ}$, the test segment of $22 \mathrm{~mm} \times 0.9 \mathrm{~m}$ elongated about $0.14 \mathrm{~m}$ (about a $16 \%$ strain) at an impact load level of about $280 \mathrm{kN}$ after one drop. The dynamic energy absorption of the $0.9 \mathrm{~m}$ long segment was $39 \mathrm{~kJ}$, corresponding to $43 \mathrm{~kJ} / \mathrm{m}$. It is also shown that the load transferred to the bolt plate is only a small portion of the impact load, indicating the anchor close to the bolt thread provides a protection to the plate.

The field trials conducted in the mine demonstrated that the rebar bolt is unevenly loaded along its length with the maximum load at the bolt plate/thread. Furthermore, peak loads occur in the positions of opening fractures. The D-Bolts nearby are evenly loaded in each deformable section. D-Bolts can potentially survive longer than rebar bolts because premature failure due to peak loads could be avoided in D-Bolts.

\section{References}

Cai, M. and Champaigne, D. (2009) D bolt pull test at Vale Inco's North mine, Mansour Mining Inc., 5 p.

Charette, F. and Plouffe, M. (2007) Roofex - results of laboratory testing of a new concept of yieldable tendon, in Proceedings Fourth International Seminar on Deep and High Stress Mining, Y. Potvin (ed), Australian Centre for Geomechanics, Perth, Australia, pp. 395-404.

Grassel, O., Kruger, L., Frommeyer, G. and Meyer, L.W. (2000) High strength Fe-Mn-(Al, Si) TRIP/TWIP steels development - properties - application. Int. J. Plasticity, 16, pp. 1391-1409.

Jager, A.J. (1992) Two new support units for the control of rockburst damage, in Rock Support in Mining and Underground Construction, P.K. Kaiser and D.R. McCreath (ed), Rotterdam, A.A. Balkema, 1992, pp. 621-631.

Li, C.C. (2010) A new energy-absorbing bolt for rock support in high stress rock masses. Int. J. Rock Mech. Min. Sci. 47(3), pp. 396-404.

Li, C.C., Doucet, C. and Carlisle, S. (2009) Dynamic tests of a new type of energy absorbing rock bolt - the D-Bolt, in Proceedings 3rd Canada-US Rock Mech. Symposium and 20th Canadian Rock Mechanics Symposium, Toronto, Canada, 9 p.

Simser, B., Andrieux, P., Mercier-Langevin, F., Parrott, T. and Turcotte, P. (2007) Field behaviour and failure modes of modified conebolts at the Craig, LaRonde and Brunswick mines in Canada, Challenges in Deep and High Stress Mining, Y. Potvin, J. Hadjigeorgiou and D. Stacey (eds), Australian Centre for Geomechanics, Perth, Australia, pp. 347-54.

Varden, R., Lachenicht, R., Player, J., Thompson, A. and Villaescusa, E. (2008) Development and implementation of the Garford Dynamic Bolt at the Kanowna Belle Mine, in Proceedings 10th Underground Operators' Conference, Launceston, Australia, 19 p. 